\title{
The Partnership in the Asset-based Empowerment of the Community in Gedepangrango Village Kadudampit District Sukabumi Regency Indonesia
}

\author{
Atirista Nainggolan ${ }^{1}$, Didiet Widiowati ${ }^{2}$, Dwi Yuliani ${ }^{3}$ \\ \{atiristanainggolan2019@gmail.com ${ }^{1}$ \} \\ Politeknik Kesejahteraan Sosial Bandung, Indonesia ${ }^{1,2,3}$
}

\begin{abstract}
This article was written based on the action research with qualitative approach on the partnership in the asset-based empowerment of the community in Gedepangrango Village Kadudampit district Sukabumi regency, Indonesia 2016. The stages of this research comprise look, think and action in the process of circle as contended by Stringer. The purpose of this research was to obtain the design of the partnership in the community asset-based empowerment. There are community assets such as natural asset, social assets and human resources that have not fully synergized. There were economic, societal, and the environmental coaching named "Tribina" activities in the process of the partnership in the community asset-based empowerment. The evaluation of this "Tribina" activities result in the partnership model design that consisted of 4 pillars of the model, namely: the government, society, business realm, and the academic/university. This is the model of the mutuality based conventional CSR model.
\end{abstract}

Keywords: Partnership, Community Asset, Empowerment, Facilitation.

\section{Introduction}

The Indonesian government has implemented various programs on social welfare such as the poverty alleviation, disability, family and children, elderly, socio-economically women at risk, HIV/AIDS, drug abuse problem and coaching for social welfare resources. Nevertheless, there are still a big number of complicated social problems. The effort that has been implemented was comprehensive and holistic in nature, which requires the state involvement and the whole community roles in implementing those programmers. The government conducted this effort in accord with the Social Welfare Constitution Number 11, 2009 [1], stated that the government and the all of the segments of the community are responsible to the social welfare efforts. The synergy between the government and all the community elements such as the civilians and their public figures, the business realm, academics, professionals, and the government institutions is the effective strategy in the community empowerment to effectively manage their assets and to become commodity oriented. Thus, the community is able to work together in managing the socio-economic life that at once affected their living environment.

The scope of this research is the partnership design in the asset-based community empowerment that includes the partnership model, partnership activity form, nature of the partnership, elements of the partnership and the elements that are utilized in the asset-based community empowerment. 
Researchers used Davies idea, cited by Hasreat J. Ziliwu, 2007 then noted by Syaff [2] that partnership is a formal cross sector relationship between individuals, groups or organization who together have an agreement community share both risk and the benefits and review understanding a specific task the relationship regular.

The early condition of the partnership model is linear in nature between the central government, district governmental agency and the community. Each agency works in sectorial manner. The sectors such as social, women and children empowerment, tourism, health, corporation, Industry \& Trading, and the Labor has not shown the significant partnership between the institution and the synergy among community elements. For instance, the Social Ministry granted Rp. 10.000.000 for renovation of each of unworthy dwelling houses, only ten houses that has been renovated, because according to the community, this amount of money can only afford the building materials, laborer's excluded. This situation shows that the community had not synergized and utilized the financial aid.

The potential and the community resource are the community asset that can be optimized in the society empowerment to overcome the social problem. The optimization of the community asset's utilization has been hindered by the uneasiness of the human resource as the agent of change and the conductor of the activity with the scarcity of other resources that were the university students, government, business realm and the other local community elements.

This action research implements the empowerment effort that was named "Tribina", which comprised of societal, economic and environmental coaching. Even though the "Tribina" resulted a meaningful synergy movement, there is still a need to enhance and maintain the change that has been made bridging the social capital in order to maximize the community empowerment. As stated by Sadan [3] that empowerment is a process of translation from powerlessness state to relative control over life and environment.

This is in accord with the strength perspective that had been stated by Miley [4] that "applying a strengths perspective including collaboration augmented existing strengths to build new resources". Also Pehrson [5] that purposes of empowerment are increasing resources, improving self-esteem and building up the ability of people.

Facilitated by the researchers, academicians, and the polytechnic students facilitates the enhancement of the work group's capacities to perform their takes in line with Triplett and Allport [6] which stated that "the concept of social facilitation through coalition enable individuals to perform the same task".

\section{Method}

This action research uses qualitative approach, in regard with addressing community asset and applying the strength perspective by mobilizing partnership in various elements of community. Key people, community members, local institution, district government institutions together with researchers maximized the benefit of community assets with the purpose of overcoming social problems and making a social change.

\section{Result and Discussion}

Action research in community known as Community Based Action Research (CBAR) is a research with the purposes to promote people participation in problem solving [7]. Further, 
researchers used Stringers' concept of action research which comprises look-think and act that repeated in spirals. Practically, researchers together with community, and stakeholder engaged in the action research as process of empowerment.

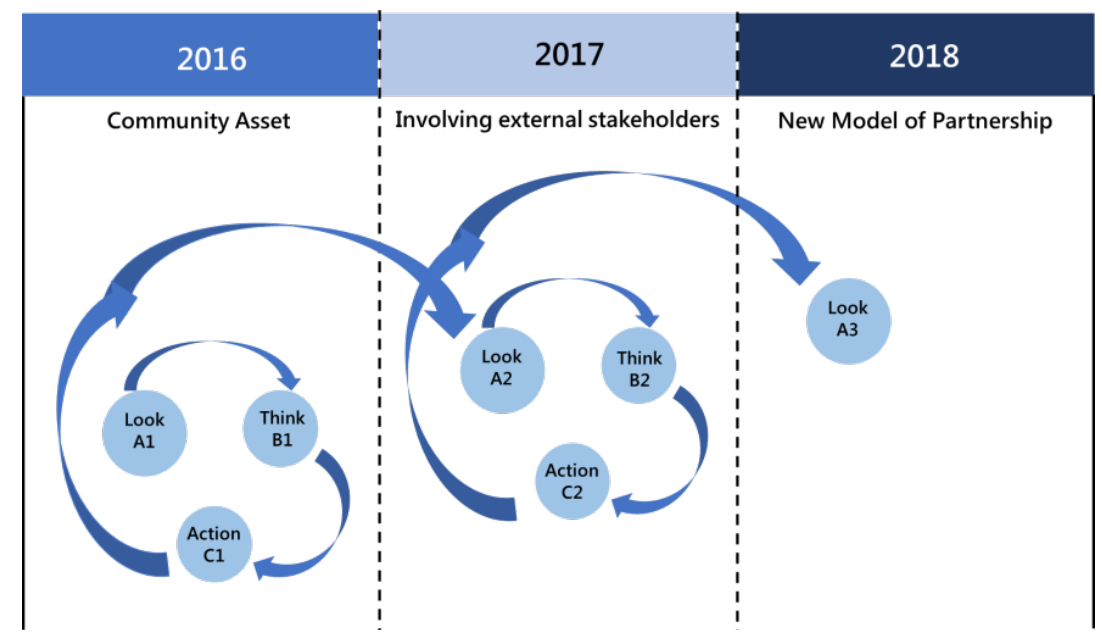

Fig. 1. Stringer CBAR Model [7].

\subsection{First Circle, 2016}

In 2016 Ministry of Social Affairs established the Gedepangrango village in Kadudampit district, Sukabumi Regency as one of welfare independent village (Desa Sejahtera MandiriDSM) based on proposal of Social Welfare Polytechnique's. The DSM program is a new breakthrough in poverty alleviation approach initiated by university. in that area, Polytechnique of Social Welfare appoints its lectures dan students to involve in the practice and social responsibility activities in this village. In the practice period, the students, continued by the lectures in the social responsibility practice, identifies the assets and resources that is owned by the village.

Eventually, the lectures of the Social Welfare Polytechnique who were DSM Facilitators in this village get inspiration to continue the community empowerment program through action research. The researchers, along with the community, them implement the mapping and asset community understanding that consist of A1 (Look), B1 (Think), C1 (Action). We can explain these actions by:

\subsubsection{A1 (Look)}

In this stage (2016) the researchers along with the community conducted community asset mapping. We can identify the assets that consist of: 1) Natural tourism that consist of Sawer waterfall, Situ Gunung lake, Cinumpang Tubing (Cigunung river); 2) Agriculture that consisted of coffee, lemon, chives, strawberry, and others; 3) Social asset that consist of art and culture such as Kaledor, Kendang Pencak, Ngabodor, Karinding; 4) Social institutions such as PKK, Karang Taruna, Mosque Welfare Board, Village Corporation, Social Welfare Center, Agriculture Group, Zakat Infaq Sodakoh (ZIS). The community village has not yet understood the way to optimize that asset in enhancing their own welfare. Because of that, the researchers 
aid them to identify that asset together and to understand the ways to develop those assets to become the welfare source for the community village. Besides that, the community also identifies the community groups that can be utilized to implement the optimization of those assets. These community groups are the youth, productive elders, PRSE, other young generations, disability groups, productive poor community, and the dwellers of unworthy dwelling houses. Also, at this step community, stakeholder and researchers addressed the model of partnership in the community as seen in figure 2 .

\section{The early partnership condition}

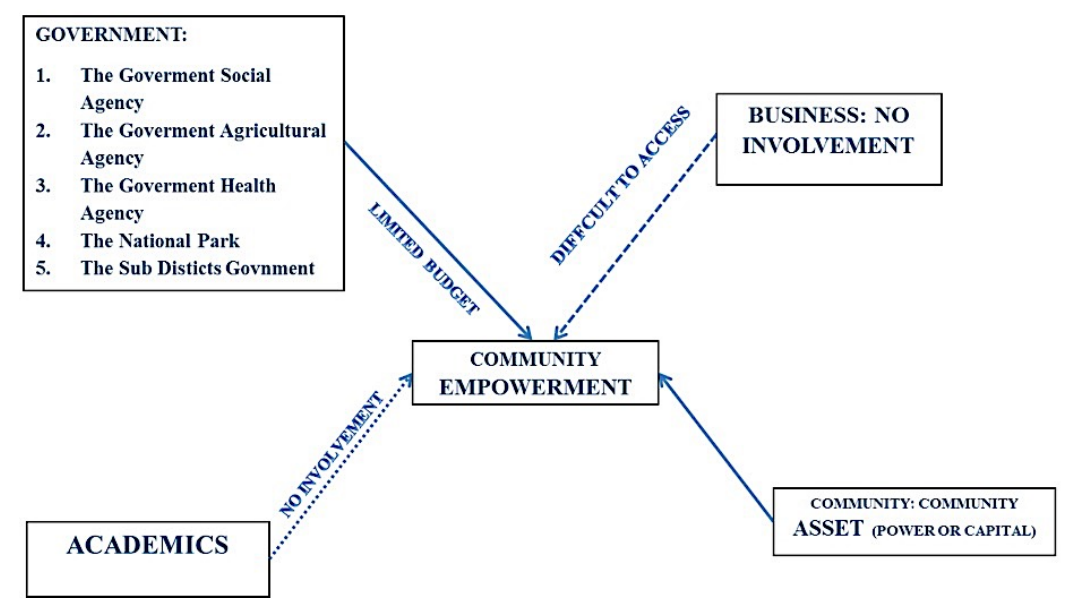

Fig. 2. The early partnership condition in Gedepangrango Village.

Green and Haines [8] assert that the community assets are "the wealth investment, source and potential, capacity or the power in the household or other community". The United Kingdom Department for International Development (DFID) in Carney [9], identifies that there are 5 (five) assets in the source of life, that are the human, physical, financial and the natural asset, and social capital. The district governmental agency such as the social, agricultural, health, transportation, sub district, and the national park as usual undertook their own program in linear corporation with their stakeholders and target groups. It means that there is not a mutual synergy among those elements. Every institution holds limited budget to accomplish their sectoral and top down program. There might be community participation in the programs but it is not seen. There is no involvement of business realm in the community empowerment, also it is difficult to access. Syariah bank, Rakata land, village villa, Panties developer, and Training Camp were still in their own business. The local government has not involved them in the mutual partnership of community empowerment.

The visitors cannot access much of the community assets such as: the Natural Potencies; rain forest, four closed tour destinations; lake, river, water fall and the national park that were not much accessible, due to the lack of transportation and narrow rocky road, agriculture, coffee, strawberries, lemon, rice, chives and other vegetables were plenty, but still traditionally managed. Therefore, the community needs education or training specifically on the food management. There are Human Resources such as the Movement Team of Family Welfare Empowerment, Village Business Board, Social Welfare Center, Islamic Education Foundation, 
The Mosque Prosperity Hall, Ta'lim Council, youth organization, Farmes Group, Family Empowerment Center and the Culture-Art such as Musical Comedy. Mostly, those are not active, some only active temporarily in special event, for instance, Youth organization and musical Comedy that is usually active at Ramadhan and independent day.

The corporation formally mentions the academicians but their role and universities' or Polytechnique's' role are not significant. It seemed that academicians just temporarily take parts in certain time like field study, field placement etc. That's why all of the assets are not mobilized optimally. The corporation consequently discontinues the community empowerment.

\subsubsection{B1 (Think)}

In the B1 (think) stage in 2016, the researchers facilitated the community and its key people to conduct: 1). Assessment of community assets through MPA; 2). Planning the integrated tourism village development; 3). Planning the way to optimize community assets; 4) Identification of resource system: Social, Agriculture, Health, Industry and Trading, Tourism agencies, National Park, and District level government; 5). Arrangement of the poor community empowerment; 6). Determining success indicators: (a). The government empowers the poor families through KUBE to increase their incomes. (b). The productive elders are able to market their hydroponic agriculture results at the tourism site and increase their incomes, (c)The youth can own rafting business, outbound transportations and facilities, and to become tour guides to increase their family incomes, (d). The disabled children and their families can market their handcrafts at the tourist site, (e)The disabled children and their families gain supervision and empowerment, (f). ZIS (Zakat Infaq \& Shudaqoh) utilization optimization, (g). The poor families with unworthy dwelling houses gain aid from Social Ministry that renovates their houses.

The community figures that participates in this activity are the Village Head, PKK Committee, Karang Taruna leader, Mosque Welfare Board Committee, Village Corporation leader, Social Welfare Center Committee, Agriculture Group Committee, Youth cadres, LK3 committee.

\subsubsection{C1 (Action)}

In this 2016 action stage, the researchers along with the community figures supervise the community in the strategy arrangement of asset development in empowering the community. The mentioned actors conduct this activity by using TOP that results the needs, such as:

a) The need of community work group where the academicians from Poltekesos and UMI conduct their supervisions;

b) The proposal arrangement to develop the new corporation group;

c) The meeting with the broader community, academicians, district and county level governments, and the business realm;

d) The coaching that consist of: organic compost processing, farm animal breeding, multiplication of agriculture results, packaging and marketing the products;

e) The socialization and formation of ZIS in every block.

Following the above points, this action stage will realize those needs by:

a) The meeting where the village head, together with the lectures and students of Social Welfare Polytechnique Bandung, initiates to form the work group; 
b) The PRSE, poor community work group, elder work group, disabled children and family, youth work group together with the researchers conduct the proposal outlining for the new corporation group;

c) The meeting with the academicians and business people to discuss the sources that can aid community assets optimization in empowering the community;

d) The coaching consists of: (a) organic compost processing, farm animal breeding, agriculture result multiplication by UMI students; (b) the packaging and marketing the product by the corporation; (c) the workshop about parenting and children rights to the target group and Family Consultation Agency; (d) the disability and parenting workshop by Health Agency's doctors; (e) Community Based Rehabilitation (CBR) capacity enhancement workshop by the Social Agency and Poltekesos; (f) CBR disability formation by the community figures and Social Agency by Poltekesos lectures; (g) elderly treatment workshop and guidance by the Health Agency; (h) Pujasera PRSE (socially and economically women at risk) group formation;

e) Mosque Welfare Board and other community figures initiates the socialization and ZIS formation in every block.

\subsection{Second Circle, 2017}

\subsubsection{A2 (Look)}

The researchers evaluate and conclude from all the activity series in 2016, beginning from A1 Look, B1 Think, C1 Action that the success indicator (B1 Think) can be achieved when all those activities involve external source system because the inadequate community assets and the regulation limitation. What we mean by the regulation limitation here is that the tourist village establishment must not damage the national park conservation. To overcome this, all these activities need the partnership with the sectoral government, business realm, and the professionals to participate the planning of the integrated tourist village. So, at this second stage, the researchers with the village, district, and community officers that are facilitated by the researchers arrange strategic planning in the partnership expansion. The activities that are conducted in the series of the partnership expansion consist of:

a) The meeting with the participant at the first cycle in preparing coordination meeting with the external stakeholders.

b) The Local Government Institutions Identification: The Government Social Agency, The Government Agricultural Agency, The Government Health Agency, The National Park, The Sub Districts Governmental, Regional Planning and Development Board, The Local Farming Institution, The Government Industry and Trade Agency, The Government Agency of Women and Child Empowerment, The Government of Tourism.

c) Business Realm Identification: PT. Ponties, Syariah Banks, Tanah Kita Rakata, Icuk Sugiarto Training Center, Village Villa.

d) Academics Identification: Social Welfare Polytechnique, University of Muhammadiyah Sukabumi.

e) Arrange the strategy and activity to establish integrated tourist village by: (1) Gaining permission from Forestry Agency to grant the tourist site's access like Sawer waterfall, Cinumpang river, Situ Gunung lake, and tubing spots; (2) Community empowerment strategy arrangement through Tribina (social, economy, and environment 
empowerment) involving external stakeholders; (3) Outlining social institutions namely PKK, Karang Taruna, Elder KUBE, Disabled Children KUBE, and Youth KUBE as the components of social tourism, because the commodity of these work groups becomes the selling products in the tourist site. The activity of the corporation groups becomes one of the targets of the social tourism; (4) To make social assets (local art and culture) as one of the tourist packages.

\subsubsection{B2 (Think)}

At the step of B2 (think), community and all stakeholder:

a) Determine the coaching schedule, source, facilitator, cost, and the workshop/coaching materials;

b) Propose the proposal to the KUBE stakeholder;

c) Plan the theater building as the venue to perform the local art and culture;

d) Arrange meeting at village level facilitated by village officials and researcher. The meeting aimed to create consensus among local institutions and key people in cooperation development;

e) Perceive an agreement of building a suspension bridge to connect Gedepangrango Village with Curug Sawer Waterfall, Situgung lake, Cigunung and Cinumpang river;

f) The planning of empowerment activities in Tribina partnership (social, economy, environment empowerment);

g) Social, Agriculture, Farming, Industry and Trading, Women Empowerment and Child Protection, Health, Tourist agencies, BAPPEDA, Gede Pangrango National Park, Poltekesos, and Muhamadiyah University attend the expanded SKPD meeting. The result of the meeting is the SKPD is willing to be the partner of Gede Pangrango village empowerment;

h) The Social Agency initiate and facilitate the KUBE formation and the unworthy dwelling houses renovation. One renovated house provides one bedroom for homestay activity;

i) BAPPEDA: coordinate the suspension bridge building planning. 10). Agriculture Agency: provides free seeds and composts, and organic compost processing coaching;

j) Farming Agency: coaches the community on how to breed goats and rabbits;

k) Industry and Trading Agency: grants permission to the formed KUBE;

1) Forestry Agency: (1) grants access by giving the permission to build the suspension bridge that connects the village to the tourist site. This bridge hangs above the national park, (2) provides room in the park for theater, (3) provides room for tourist terminal;

m) Corporation: coaches the community on how to pack and to market KUBE products;

n) Women Empowerment and Children Protection Agency: provides workshop child parenting, good parenting, and children rights to the target groups;

o) Health Agency: the doctor conducts the disability workshop, disabled children health check, workshop and free health check to elders;

p) Tourist Agency: (1) provide trainings to the village youth to become tour guides, (2) organizing tourist objects, (3) promotes Destarasi tour package;

q) National Park: provides rafting, outbound spots, and camping grounds facilities around Situ Gunung lake;

r) Syariah Bank: lends fund to PT. Ponties via the lending of confidential letter country Syariah (SBSN);

s) Poltekesos: provides a number of students and lectures for supervising; 
t) Muhammadiyah University Sukabumi (MUS): provides a number of students from food and farming technology for food and farm animals processing.

\subsubsection{C2 (Action)}

In the C2 (action) stage in 2017, the researchers facilitated the community and stakeholders to conduct:

a) Conducting coordination meeting with the all of the identified professional and institution financially facilitated by Regional Planning and Development Board as host of this meeting.

b) Establish the integrated tourist village that consists: suspension bridge building, tourist terminal building, camping ground establishment, optimize Cinumpang river as rafting area, theatre building, coaches the village youth to become tour guides and outbound facilitator, and coaches the PRSE to build the food court.

c) Conduct the Tribina partnership empowerment activities as:

Table 1. Plan of "Tribina" Empowerment Activities

\begin{tabular}{|c|c|c|c|}
\hline No & Tribina Areas & Activities & Partnership \\
\hline \multirow[t]{10}{*}{1.} & \multirow[t]{10}{*}{$\begin{array}{l}\text { Social } \\
\text { empowerment }\end{array}$} & $\begin{array}{l}\text { Good parenting and children } \\
\text { rights workshop }\end{array}$ & $\begin{array}{lll}\text { Women empowerment } & \text { and } \\
\text { children protection agency } & \\
\end{array}$ \\
\hline & & LK3 Team committee training & $\begin{array}{l}\text { Social, academic, and society } \\
\text { catherization agency }\end{array}$ \\
\hline & & Disability RBM formation & $\begin{array}{l}\text { Social, academic, and society } \\
\text { catherization trade department }\end{array}$ \\
\hline & & $\begin{array}{l}\text { Elderly productive economy } \\
\text { corporation group formation }\end{array}$ & $\begin{array}{l}\text { Social, academic, and society } \\
\text { catherization trade department }\end{array}$ \\
\hline & & $\begin{array}{l}\text { Women at social risk KUBE } \\
\text { formation }\end{array}$ & $\begin{array}{l}\text { Social, academic, and society } \\
\text { catherization trade agency, } \\
\text { cooperation }\end{array}$ \\
\hline & & $\begin{array}{lll}\begin{array}{l}\text { Youth } \\
\text { (Tubing) }\end{array} & \text { KUBE } & \text { formation } \\
\end{array}$ & $\begin{array}{l}\text { Tourism, social agency, national } \\
\text { park }\end{array}$ \\
\hline & & $\begin{array}{l}\text { Elderly } \mathrm{RBM} \quad \text { catherization } \\
\text { training }\end{array}$ & $\begin{array}{l}\text { Social, academic, health agency, } \\
\text { public figures }\end{array}$ \\
\hline & & $\begin{array}{l}\text { Communication for disability } \\
\text { children and family forum } \\
\text { formation }\end{array}$ & $\begin{array}{l}\text { Social, academic, health agency, } \\
\text { public figures }\end{array}$ \\
\hline & & $\begin{array}{l}\text { ZIS socialization and } \\
\text { optimization fund (zakat, infaq, } \\
\text { shodaqoh) in every block }\end{array}$ & $\begin{array}{l}\text { Mosque Welfare Board (MWB), } \\
\text { public figures }\end{array}$ \\
\hline & & $\begin{array}{lrr}\begin{array}{l}\text { Productive } \\
\text { corporation } \\
\text { formation }\end{array} & \text { family } & \text { gronomy } \\
\end{array}$ & $\begin{array}{l}\text { Social, farming agency, } \\
\text { academic }\end{array}$ \\
\hline \multirow[t]{3}{*}{2.} & \multirow{3}{*}{$\begin{array}{l}\text { Economy } \\
\text { empowerment }\end{array}$} & Permission grant by BAPPEDA & BAPPEDA \\
\hline & & $\begin{array}{l}\text { Packaging and marketing PRSE } \\
\text { productive economy activity, } \\
\text { elderly, poor family, and } \\
\text { disabled children }\end{array}$ & $\begin{array}{l}\text { Industry and Trade agency, and } \\
\text { cooperation }\end{array}$ \\
\hline & & $\begin{array}{l}\text { Destarasi tourism package } \\
\text { promotion }\end{array}$ & Tourism agency \\
\hline
\end{tabular}




\begin{tabular}{|c|l|l|l|}
\hline & & $\begin{array}{l}\text { Suspension bridge building } \\
\text { above Gunung Gede Pangrango } \\
\text { National Park }\end{array}$ & $\begin{array}{l}\text { Syariah Bank through SBSN loan } \\
\text { for funding (confidential letter } \\
\text { country Syariah) }\end{array}$ \\
\hline 3 & $\begin{array}{l}\text { Natural } \\
\text { (environment) } \\
\text { empowerment }\end{array}$ & $\begin{array}{l}\text { Cinumpang river utilization for } \\
\text { rafting that involves the youth }\end{array}$ & $\begin{array}{l}\text { - National park } \\
\text { - Tourism agency } \\
\text { - BAPPEDA }\end{array}$ \\
\cline { 3 - 4 } & $\begin{array}{l}\text { Sawer waterfall optimization as } \\
\text { a tourism object }\end{array}$ & $\begin{array}{l}\text { - Tourism agency } \\
\text { - Tanah Kita Rakata Land }\end{array}$ \\
\cline { 3 - 4 } & $\begin{array}{l}\text { Situ Gunung lake optimization } \\
\text { by camping park building } \\
\text { around it }\end{array}$ & $\begin{array}{l}\text { - PT Ponties } \\
\text { - Bank Syariah Foundation }\end{array}$ \\
\cline { 3 - 4 } & $\begin{array}{l}\text { Unworthy houses renovation to } \\
\text { support Gedepangrango as a } \\
\text { tourism village }\end{array}$ & Social Agency \\
\hline
\end{tabular}

d) Creates the new partnership model in the community assets empowerment through the innovation of Integrated Tourist Village (ITV). The village is the tourism that combines social, economy, and natural aspects. All of the parties in this research expects this village to be the driving force in overcoming economy and social. By doing so, the economic life will be active and implies to the Gede Pangrango community life quality enhancement.

\subsection{Third Circle, 2018}

\subsubsection{A3 (Look)}

In 2018, the researchers evaluated all of the activities from A1, B1, C1-A2, B2, C2 with results:

a) The formation of the integrated village that consists of: a) tourist terminal that exists to empower the village youth as tourist guides; b) the food court that exists to sell the elder KUBE, PRSE, disabled children, poor community products; c) the camping ground that involves the village youth as the out bound facilitator.

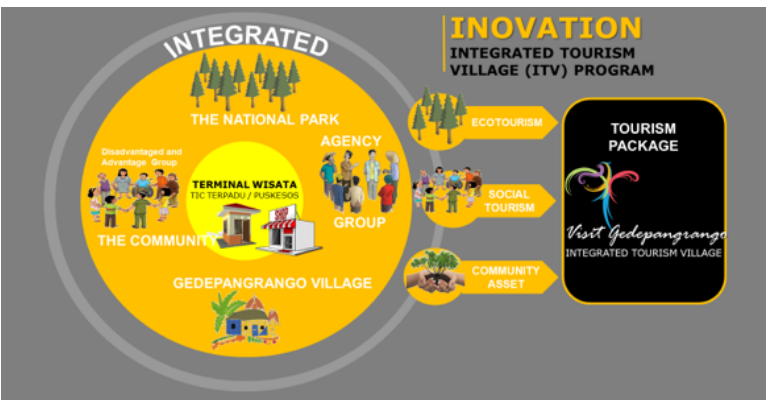

Fig. 3. Integrated Tourism Village

The aim of Integrating community assets was the empowerment for both disadvantaged and diverse advantaged groups. They altogether acted as the resources for creating an integrated tourism village and at once overcoming social problems. 
b) The achieved new partnership by the Gede Pangarango community empowerment.

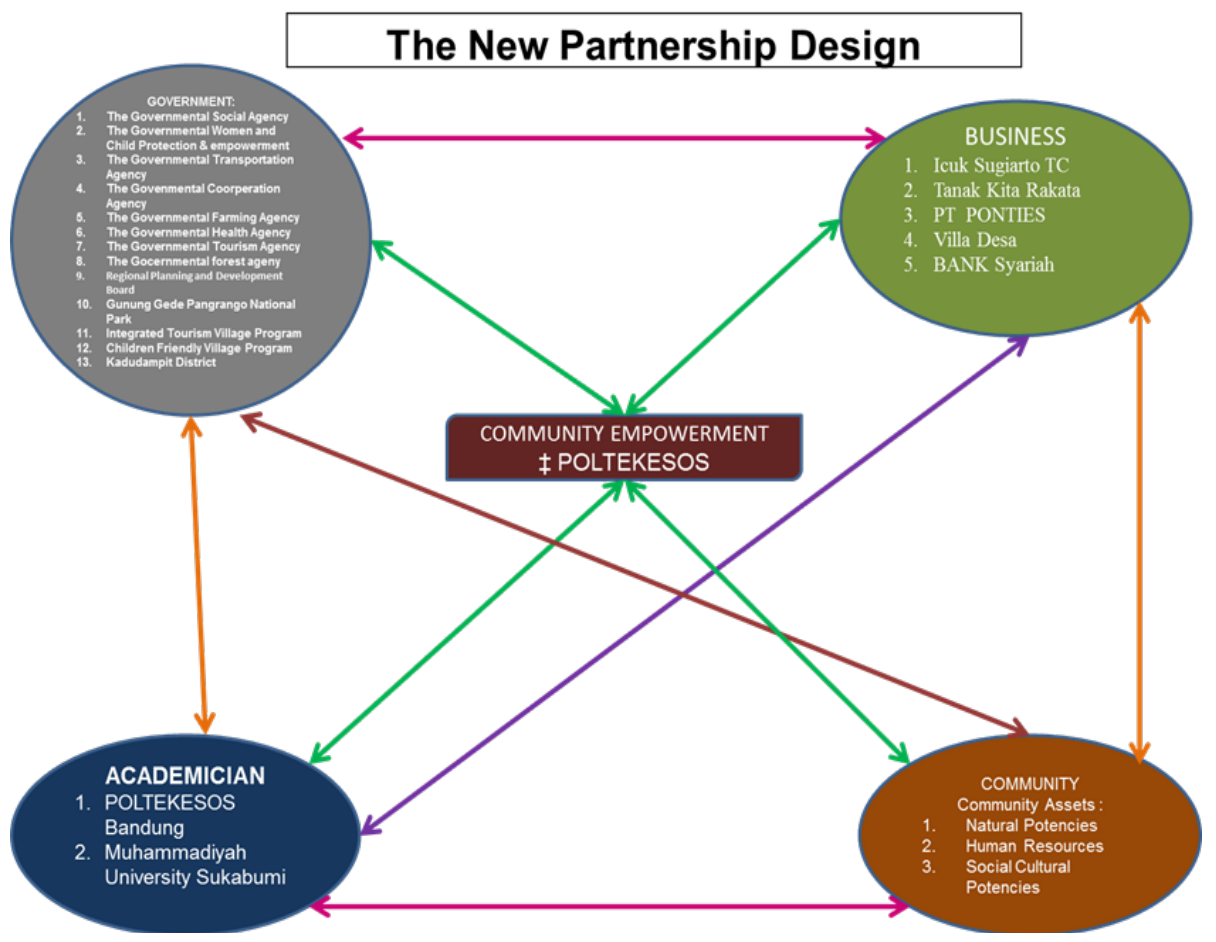

Fig. 4. The New Partnership Design

The unoptimized partnership becomes the broader partnership that involves 13 SKPDs.

c) The establishment of the suspension bridge as one of the prominent tourism objects Gede Pangrango village.

d) The realization of the integrated village implies to: (a). The income incline Gede Pangrango village community; (b). The increase of job fields in Gede Pangrango village where the youth/villagers become rent motorcycle, public transportation drivers, tour guides, out bound trainers, etc.

e) The achieved asset-based community empowerment through the partnership by the outlined indicator.

f) The success indicator of asset-based community empowerment through the partnership is: (a) The productive elders can continue their productive economic corporation (in hydroponic planting) without supervision; (b). The social economy at risk women can market their productive economy corporation products (the processed vegetables); (c). The productive youth now has become the out bound, rafting facilitator, rent and public transportation drivers that can increase their family incomes; (d). The disabled children can create handicrafts and market them in the tourist site, (e). The poor families that gains KUBE and Social Ministry aid can increase their family income by opening lamb satay distros; (f). Food court establishment at the tourist site. 
g) Stakeholder response: Kadudampit district government demands that the asset-based community empowerment through partnerships can be replicated at Sukamaju village in Gede Pangrango's west side.

\section{Conclusion}

The strengths of all client's system were the elderly, youth and the poor resources to initiate and to synergize the empowerment processes. Therefore, the researchers mobilize the resources that is both available within the target group system and their surroundings. Economically, the disadvantaged groups, elderly, the poor and women socially and economically at risk gained more abilities to produce economic goods as well as to the get job opportunities to be more effective in functioning

Recognizing that to synergize various available change agent systems was the major point in empowerment process. Contextually, the partnership design was based on the "tribina" uses the four pillars, namely the government agencies, business realm, academicians/university and the local community. This model is the mutualistic partnership model as the idea of the partnership noted by Reed and Reed [10] that one of partnership type is the social responsibility. They defined Corporate Social Responsibility Partnership Model (CSRPMs) as a voluntary corporation in which the individual corporations are not forced to join them and were not sanctioned if they chose not to join. People are only bound by agreements that they freely made. One of the prominent areas of CSRPMs was the humanitarian assistance and the disaster relieve. The activities of this area encompass the social program, especially the health care and the education.

\section{References}

[1] Undang-Undang Republik Indonesia Nomor 11 tahun 2009, “Kesajahteraan Sosial.” [Online]. Available: https://aturanyangmengatur.blogspot.com/2012/04/undang-undang-republikindonesianomer 256.html. [Accessed: 13-Sep-2019].

[2] Syaff, "Advokasi, Kemitraan dan Pemberdayaan Masyarakat," 2014. [Online]. Available: http://materi-paksyaf.blogspot.com/2014/04/advokasi-kemitraan-dan-pemberdayaan.html [Accessed: 27-Aug-2019].

[3] E. Sadan, "Developing a Theory of Empowerment," 2001. [Online]. Available: www.elisheva_sadan_empowerment chapter3.com. [Accessed: 29-Aug-2019].

[4] K. K. Miley, M. O’Melia, and B. DuBois, "Generalist social work practice: An empowering approach," 2001.

[5] P. Pehrson, "What is the Empowwerment theory as it relates to social work?," 2018. [Online]. Available: https://www.quora.com/what-is-the-empowerment-theory-as-it-relates-to-socialwork. [Accessed: 09-Sep-2019].

[6] A. Wallace, "An Extention of Social Facilitation Theory to the Decision-Making Domain," $J$. Clemson Univ., 2011.

[7] E. T. Stringer, "Socially responsive educational research: Linking theory and practice," Theory concepts Qual. Res. Perspect. from F., pp. 141-162, 1993.

[8] G. P. Green and A. Haines, Asset building \& community development. Sage publications, 2015.

[9] D. Carney, Livelihoods approaches compared: A brief comparison of the livelihoods approaches of the UK Department for International Development (DFID), CARE, Oxfam and the United Nations Development Programme (UNDP). Department for International Development, 1999.

[10] A. M. Reed and D. Reed, "Partnerships for development: Four models of business involvement," 
J. Bus. Ethics, vol. 90, no. 1, p. 3, 2009. 